\title{
Spiritual Connections and Complexities in Rural Communities: A Case Study of Annang Farmers in Akwa Ibom State, Nigeria
}

\author{
Valerie Aphie Solomon ${ }^{1, *}$, Margaret Abba Yaro ${ }^{2}$ and Ifiok David Ekong ${ }^{1}$ \\ ${ }^{1}$ Department of Agricultural Economics and Extension, University of Uyo, Nigeria \\ ${ }^{2}$ Department of Urban and Regional Planning, Cross River University of Technology Calabar, Nigeria
}

\begin{abstract}
The study examined spiritual and religious connections and complexities in rural communities using the indigenous Annang people of Akwa Ibom state as a case study. The research made use of primary data from 150 randomly selected respondents and 8 purposively selected key informants, using questionnaires and interview schedules. Data analysis was both descriptive and inferential. Findings indicate that $94 \%$ of the respondents were aged between 21 and 60years, $94 \%$ had some form of formal schooling, all respondents were Christians, $61.3 \%$ being married and $92 \%$ earned a maximum of NGN50, 000 monthly. $52 \%$ of respondents had farming as their primary occupation. Respondents were highly inclined to spirituality with $98.7 \%$ of respondents attending religious functions at least once a week and a further $62.7 \%$ relying on fate, miracles and protection from charms and amulets. The multiple regression results showed that there was no significant relationship between selected sociological factors and respondent's inclination to spirituality, while the T-test analysis showed that there was no difference in the inclination to spirituality between men and women. The study recommends that formal education with focus on the enlightenment, re-orientation, and counselling of individuals be effectively initiated to reduce the levels of inclination to spirituality. This will ensure that local level decision making is objective and based on facts.
\end{abstract}

Keywords: Spiritual connections, rural communities, Annangs, Nigeria.

\section{INTRODUCTION}

Africans have been regarded as being "incurably religious and spiritual" and beyond a shadow of doubt, the most definable characteristic of African people is the intrinsic ubiquitous reverence for divinity. Africans are distinctively religious because of our spirituality, and we are not talking denominations or names of various religious systems living in Africa but that distinctive personality found everywhere in ancient and modern Africa that reformed itself into Islam, Christianity and so forth (Opoku, Davis and Shahadah 2012). Umoh (2013) asserts that from the dawn of human existence, every known civilization that ever existed on the planet had something common in them these were spiritualties, legends and superstitions and these were a crucial part of man's culture. Spirituality means different things to different people, so, there is no single widely agreed definition of the term. For some, it is about participating in organized religion (e.g. going to church, or a mosque etc.), while for others, it is more personal. Adopting the definition of Sina (2012), spirituality is defined as the quality of one's sensitivity to the things that are not of material and corporal nature. This encompasses the many rituals and beliefs that moderate ones relationship with the supernatural.

The belief in the spiritual among the Annangs of Akwa Ibom state is a way of life and it is believed that

${ }^{*}$ Address correspondence to this author at the Department of Agricultural Economics and Extension, University of Uyo, Nigeria;

E-mail: valasolomon@yahoo.com, valerieaphie@uniuyo.edu.ng spiritual entities protect their adherents from misfortune and sicknesses, they adjudicate disputes and punish personal or communal immorality through droughts, fires and other catastrophes. Also, they counter malevolent intensions by others and/or ghostly entities, even political rivalries, inheritance disputes, marital choices and the clearing of a farm are incorporated and explained within this spiritual framework. It is assumed that these spiritual beliefs and the religiosity of the people have implications for rural growth and development. The study therefore, attempted to achieve the following objectives: identify the respondents and relate some of their socioeconomic characteristics to their inclination to spirituality, document the prevalent spiritual beliefs of the people, determine their degree of spirituality and religiosity, compare the inclination to spirituality between male and female respondents and evaluate the implications of findings for rural development.

\section{RESEARCH METHODOLOGY}

\subsection{The Study Area}

The Annang people of Akwa Ibom state occupy eight (8) of the thirty-one (31) Local Government Areas of the stateviz: IkotEkpene, ObotAkara, EssienUdim, Abak, EtimEkpo, OrukAnam, Ika and Ukanafun. The area is known to have fought several tribal wars in recent history, chief among which are the wars against the Igbos of Ngwa Igbo in order to preserve their territorial integrity and farmlands (Udo, 1983). The 
majority of the people living in the rural areas are engaged in farming and other agriculture based livelihoods. The landscape is predominantly plain and deep-lying with no point rising to 300 feet above sea level. The typical pattern of rainfall is bi-modal with a two-week break in August generally referred to as "the August break". Strong harmattan winds occur between December and January, and the land is generally humid. Common crops growing there include Raphia palm, oil palm trees, cassava, yam and a variety of fruits and vegetables.

\subsection{Study Population, Sampling Procedure and Sample Size}

The study population included all adults living in farming communities in the eight Annang local government areas of Akwa Ibom state, from 18 to 100 yearsold. A multi-staged random sampling procedure was used to select samples. In this method, first all Annang speaking local government areas were selected, and 2 local government areas were randomly selected from this number. Then 2 blocks were selected from each of the local government areas and 2 cells were selected from each block (using the AKADEP enumeration list as a guide), and finally some households were selected for interview in those cells. In all these stages, the selection was performed randomly. Since the total number of people per cell were not the same, the number of respondents selected from each block was proportional to its population (using the proportionate stratified random sampling technique). This was also randomized and the distance between households taken into consideration (using the systematic sampling technique). Two key informants -1 male and 1 female were selected per cell for in-depth interview. Age, occupation, sex and the formal position of authority within the community's social structure were used as the criteria for selection.

\subsection{Method of Analysis}

The primary data obtained were analyzed using descriptive statistical tools such as frequency distribution, percentages and means and presented in tabular forms. The prevalent spiritual beliefs and religiosity of the people were documented, while the relationships existing between selected socioeconomic characteristics of respondents and inclination to spirituality were determined using the multiple regression; and the t- test was used to compare inclination between the male and female group.

\section{RESULTS AND DISCUSSION}

3.1. Socio-Economic Characteristics of Annang Farmers in Farming Communities of Akwa Ibom State

Table 1: Personal Characteristics of Respondents

\begin{tabular}{|c|c|c|}
\hline Characteristics & Frequency & Percentage \\
\hline \multicolumn{3}{|l|}{ Sex } \\
\hline Male & 75 & 50.0 \\
\hline Female & 75 & 50.0 \\
\hline Sub-Total & 150 & 100 \\
\hline \multicolumn{3}{|l|}{ Age (In Years) } \\
\hline$\leq 20$ & 24 & 16.0 \\
\hline $21-30$ & 51 & 34.0 \\
\hline $31-40$ & 37 & 24.7 \\
\hline $41-50$ & 20 & 13.3 \\
\hline $51-60$ & 12 & 8.0 \\
\hline $61-70$ & 6 & 4.0 \\
\hline Total & 150 & 100 \\
\hline \multicolumn{3}{|l|}{ Educational Status } \\
\hline Formal & 141 & 94 \\
\hline Non-Formal & 2 & 1.3 \\
\hline No Education & 7 & 4.7 \\
\hline TOTAL & 150 & 100 \\
\hline \multicolumn{3}{|l|}{ Years of Formal Schooling } \\
\hline $1-5$ & 14 & 9.9 \\
\hline $6-10$ & 40 & 28.1 \\
\hline $11-15$ & 76 & 58.5 \\
\hline $16-20$ & 12 & 8.5 \\
\hline Total & 142 & 100 \\
\hline \multicolumn{3}{|l|}{ Marital Status } \\
\hline Single & 43 & 28.7 \\
\hline Married & 92 & 61.3 \\
\hline Widowed & 13 & 8.7 \\
\hline Separated/Divorced & 2 & 1.3 \\
\hline Total & 150 & 100 \\
\hline \multicolumn{3}{|l|}{ Household Headship } \\
\hline $\begin{array}{l}\text { Yes, I'm my household } \\
\text { head }\end{array}$ & 68 & 45.3 \\
\hline $\begin{array}{l}\text { No, I'm not the household } \\
\text { head }\end{array}$ & 82 & 54.7 \\
\hline Total & 150 & 100 \\
\hline \multicolumn{3}{|l|}{ Household Size } \\
\hline $1-10$ & 120 & 80 \\
\hline $11-20$ & 29 & 19.33 \\
\hline $21-30$ & 1 & 0.67 \\
\hline Total & 150 & 100 \\
\hline
\end{tabular}


(Table 1). Continued.

\begin{tabular}{|c|c|c|}
\hline \multicolumn{3}{|l|}{ Number of Children } \\
\hline $1-3$ & 42 & 42.42 \\
\hline 4-6 & 42 & 42.42 \\
\hline $7-9$ & 14 & 14.14 \\
\hline $10-12$ & 1 & 1.01 \\
\hline Total & 99 & 100 \\
\hline \multicolumn{3}{|l|}{ Children from the Same Parents } \\
\hline Yes & 87 & 58 \\
\hline No & 63 & 42 \\
\hline Total & 150 & 100 \\
\hline \multicolumn{3}{|l|}{ Monthly Income (In NGN) } \\
\hline$\leq 50,000$ & 138 & 92 \\
\hline $50,001-100,000$ & 9 & 6 \\
\hline $100,001-150,000$ & 3 & 2 \\
\hline Total & 150 & 100 \\
\hline \multicolumn{3}{|l|}{ Type of House } \\
\hline Thatch house & 12 & 8 \\
\hline Bungalow & 134 & 89.33 \\
\hline Storey building & 4 & 2.7 \\
\hline Total & 150 & 100 \\
\hline \multicolumn{3}{|c|}{ Mode of Acquiring Accommodation } \\
\hline Family house & 116 & 77.3 \\
\hline Owned outright & 26 & 17.3 \\
\hline Rented & 6 & 4.0 \\
\hline Inherited & 1 & 0.7 \\
\hline Gift/entitlement & 1 & 0.7 \\
\hline Total & 150 & 100 \\
\hline \multicolumn{3}{|l|}{ Residential Status } \\
\hline Born and bred here & 88 & 58.7 \\
\hline Resident here & 55 & 36.7 \\
\hline Visit the village often & 5 & 3.33 \\
\hline $\begin{array}{l}\text { Retired and residing in the } \\
\text { village now }\end{array}$ & 2 & 1.33 \\
\hline Total & 150 & 100 \\
\hline \multicolumn{3}{|l|}{ Farming } \\
\hline $\begin{array}{l}\text { Yes, farming is my primary } \\
\text { occupation }\end{array}$ & 78 & 52.0 \\
\hline $\begin{array}{l}\text { No, farming is not my } \\
\text { primary occupation }\end{array}$ & 72 & 48.0 \\
\hline Total & 150 & 100 \\
\hline \multicolumn{3}{|l|}{ Off-Farm Occupation } \\
\hline Trading & 39 & 26.0 \\
\hline Government salaried job & 16 & 10.7 \\
\hline Private salaried job & 65 & 43.3 \\
\hline Crafts and artisans & 30 & 20.0 \\
\hline Total & 150 & 100 \\
\hline
\end{tabular}

(Table 1). Continued.

\begin{tabular}{|c|c|c|}
\hline \multicolumn{3}{|l|}{ Type of Farming } \\
\hline Food crops & 96 & 64.0 \\
\hline Livestock keeping & 33 & 22.0 \\
\hline Cash crops & 18 & 12.0 \\
\hline Tree crops & 3 & 2.0 \\
\hline Total & 150 & 100 \\
\hline \multicolumn{3}{|l|}{ Years in Farming } \\
\hline $1-20$ & 132 & 88 \\
\hline $21-40$ & 16 & 10.7 \\
\hline $41-60$ & 2 & 1.3 \\
\hline Total & 150 & 100 \\
\hline \multicolumn{3}{|c|}{ Expenditure on Food (NGN) } \\
\hline $1-20,000$ & 106 & 70.7 \\
\hline $20,001-40,000$ & 40 & 26.7 \\
\hline $40,001-60,000$ & 2 & 1.3 \\
\hline $60,001-80,000$ & 1 & 0.7 \\
\hline $80,001-100,000$ & 1 & 0.7 \\
\hline Total & 150 & 100 \\
\hline
\end{tabular}

Source: Field Survey 2015.

\section{Sex}

Table 1 confirms the population of the study was evenly distributed between $50 \%$ males and $50 \%$ females. This agrees with the estimation of the 2006 national census figure that men and women were evenly spread in the region. Also, conscious efforts were made to mainstream gender in the research. Consequently, from a total 150 respondents, there were 75 males and 75 females.

Age

Table 1 shows that majority of respondents (58.7\%) were within the $21-40$ years age bracket. This is an economically active age range and they are expected to contribute actively to the growth of their communities. It has to be noted that the ages of some individuals were estimated and not exact, as they did not know their actual ages. With the mean age of respondents at 33.7years and low dependence ratios, this will mean that labour is readily available for agricultural activities in the study area, as respondents are expected to be employed and to employ their human and non-human resources to gain income.

\section{Education Status (Expressed in Total Number of Years of Formal Schooling)}

As indicated on Table 1, about $94 \%$ of the respondents had acquired some form of formal 
schooling, and majority (58.5\%) had from 11 to 15 years of formal education. This result shows that a majority $(62 \%)$ of the respondents had at least attended senior secondary and tertiary level education. The mean number of years of formal schooling is 9.6, implying that respondents had at least acquired junior secondary level education. This high level of literacy agrees with FERT (2001) report that Akwa lbom State is generally regarded as an educationally advantaged State because of the availability of various educational institutions and opportunities in the State. With this high literacy level, it is assumed that individuals in the study area will be less inclined to spirituality as given by past literature.

\section{Religion}

All respondents (100\%) in the study were Christians. This is so, because the predominant religion in the area is Christianity. And though some traditional worshippers exist within the population, they will describe themselves as Christians as Christianity is the predominant religion in the area and even known traditional worshippers also attend church services. The overarching theme and area of commonality to note here among respondents is their belief in the existence of a sovereign and an all knowing God, who decides ultimately, the outcome of their day to day actions or inactions. This belief system is like a doubled-edge sword as it could make the respondent rely so much on fate and thereby not take actions when he should, while also having a stabilizing effect when things do not go as planned.

\section{Marital Status}

Also Table 1 presents information on the marital status of respondents in the study. About $61.3 \%$ of the respondents were married. The high percentage of married respondents in the study area is consistent with Ekong (2003), who noted that getting married is a highly cherished value among ruralites in Nigeria not only because of the need for children and the continuation of the family name, but also because in some areas, the woman forms a vital source of unpaid family labour. In rural communities of Akwa Ibom state generally, and among the Annangs in particular, a couple is not considered 'duly married' even after being wedded in church or marriage registry without going through the traditional marriage ceremony. It is usually a community affair and prestigious to both the extended and nuclear families. And also an opportunity for members of the extended family from both sides to congregate, exchange gifts, eat and drink together. The specific rites and rituals and the cost however, vary from family to family. A 'duly married' woman must return the dowry paid on her if her husband divorces her, otherwise she still remains officially his wife and all children after the divorce still belongs to the previous husband. Divorce is therefore not popular and every family encourage their children not only to get married but also to stay married. Of the population that were married, $58.7 \%$ of them were in their first marriage, while $41.3 \%$ had remarried or were never married but had a child for another individual before marrying someone else. This is so because the cultural environment permits a woman to be married only to one man at a time, while the men could be polygamous if they had the ability. Of the population of 75 males in the study, $34.7 \%$ had no wives at the time of data collection (and though some had women with them, they were not formally married), $58.7 \%$ had one wife, while $6.6 \%$ of them had more than one wife. The single men can make do with their monthly incomes and therefore will be less bothered about increased agricultural productivity, as they do not have a family to take care of. Men with families will think differently and be more concerned about farming, as it provides more food for the family. Consequently, when responsibilities grow and incomes do not grow proportionately, there is the tendency that the rural man may become fatalistic and more reliant on spirituality.

\section{Household Headship}

As shown in Table 1, only $45.3 \%$ of respondents in the study were household heads while $54.7 \%$ were not. This can be better understood when one considers that the study was carried out in a rural area, wherein family members live in nucleated settlements around each other. This provides for more than one generation of offspring to live together within the same compound, while the eldest or most efficient member of the family circle is regarded as the family head. This implies that it is common within the area to find men with families, describing their own older parents who live with them as the household head. Again, the rural-urban migration of able-bodied youths to cities in search of better jobs, leaves only their aged parents at home to take care of the wives and children they have, making them the household heads. Should the aged members of the household be the household heads, the stories and education they give to succeeding family members will be based on their own wealth of knowledge and experiences with nature, which are largely based on the spiritual belief system. 


\section{Household Size}

Eighty percent $(80 \%)$ of respondents had between 1 and 10 members in their households with $84.84 \%$ having from $1-6$ biological children within the household, of which $58 \%$ children from the same parents, as presented in Table 1. FOS (2002) stated that the probability of being poor increases, with household size. Udoh and Omonona (2005) also reported that the higher the household size in rural farming households in Akwa lbom State, the higher the likelihood and intensity of poverty in the households. The relatively low number of children reflects a high level of literacy among the respondents to rear only the number of children they can cater for, but if we remember that we are dealing with a rural population, with low income levels, low outputs, low savings and low investments, then it can be argued that such relatively low number of children may be too large for certain individuals within the population. This means that some children within the population will lack certain basic requirements for their development into adults, which they may have to provide for themselves. A good example of this will be child labour which is a common problem in the state. Another point to note is that about $42 \%$ of the children in the study did not grow up with the same set of parents.

\section{Estimated Average Monthly Income}

$92 \%$ of the respondents earned an estimated monthly income of NGN50, 000 or less (about $\$ 250$ ). The data on Table 1 reveals that Respondents were low income earners. Some of these values were not direct incomes from the employment of productive resources; they included transfer payments to relatives who were not gainfully employed (e.g. monthly allowance given by Husband to the wife). Also, some of the respondents, particularly the women, never had a real estimate of how much they earned monthly, since these changed depending on the needs to be satisfied and the funds the household head gave as allowance.

\section{Social Status}

Certain indexes were used in describing the social status of the respondents. They are housing type, mode of house acquisition and residential status. Housing standard in developing countries is an important indicator of the socio-economic status of rural dwellers in Akwa Ibom State (Udoh, 2005). As shown in Table 1, 89.33\% of the respondents lived in bungalows, $2.7 \%$ lived in storey buildings while $8 \%$ lived in thatch houses. Also, $77.3 \%$ of the respondents lived in their extended family houses, $17.3 \%$ out rightly owned the buildings they lived in, $4.0 \%$ lived in rented apartments, while $1.4 \%$ either inherited the houses, or were given as gifts or allocations for administrative/ ministerial duties. This data reveals the prevalence of the extended family structure in the study area which is typical of the Annang family structure in Akwa Ibom State. The extended family unites at least three generations of nuclear families through the extension of the parent-child rather than the husband-wife relationships. The emphasis is in the blood ties between relations. Among the traditional Annangs, members of the nuclear family get their identity from the extended family and the ties between the nuclear and extended families are so strong that the head of the extended family could call the head of the nuclear family to order on any matter within the nuclear family. For instance, a man may not give out his daughter in marriage without due consultation and information of the extended family. However, each nuclear family maintains some autonomy in terms of its day-to-day decisions and the economic management of its own affairs (Ekong, 2003). Inheritance may also be claimed either through the extended or nuclear family, and the 'debt of sponsorship' also strengthens the link between the nuclear and extended families, even when the nuclear family has neolocal residence. The data reveals that though $89.3 \%$ of the respondents lived in concrete buildings, only $17.3 \%$ of those respondents could have had the resources to raise the building on their own. This reveals a low standard of living among the population.

On residential status, Table 1 also shows that $58.7 \%$ of the respondents were born and bred in the study area, $36.7 \%$ were fully resident in the area at the time of data collection, and $3.33 \%$ lived outside the area but visited the village regularly, while $1.33 \%$ were retirees who now live in the village. About $29 \%$ of the respondents came from prominent family backgrounds, and only $36 \%$ of the respondents were members of associations or social groups within the community. Majority of the respondents have limited view of the world as they have not left their villages since birth. As a result, they stick to the things they have learnt and have been told by their older community members. They reject new practices as they may feel uncomfortable with it and as a result, remain unenlightened, poor and stagnated.

\section{Livelihood Activities}

Farming was the primary source of livelihood for about $52.0 \%$ of the respondents as shown in Table 1 , 
while $48.0 \%$ had other primary sources of income. This result is in consonant with Berth (2004) who stated that Agriculture is the mainstay of people's livelihood in rural sub-Saharan Africa. For Respondents (including those to whom farming is primary), who worked off farm, $26.0 \%$ engaged in trading, $10.7 \%$ were involved in government salaried jobs, $43.3 \%$ had private salaried jobs, and $20.0 \%$ were craftsmen and artisans. However, as shown in the table, all respondents were into one farming area or the other (mainly to provide food to supplement that provided by their incomes). About $64 \%$ of the respondents were into food crops, $22.0 \%$ kept livestock, $12.0 \%$ cultivated cash crops, while $2 \%$ planted tree crops. Majority of respondents $(88 \%)$ have from one to 10 years of farming experience. This data stresses emphatically, first, that the incomes accruable to the respondents were not enough to satisfy the food demands of their households. And Secondly, though all the respondents were into one form of farming or the other for about 10 years, majority of them were mainly into small scale crop production, solely to provide sufficient food for their households (while using the available incomes to address other pressing needs), and then to sell what remained after consumption. To drive this point home, data gathered from the field revealed that $59.4 \%$ of the respondents consumed about $61-100 \%$ of their farm produce (and even so, $75.4 \%$ of the respondents could not still afford in-between meals). Lastly, agricultural productivity in the area is not enough to meet the food demands of the teaming population while making no meaningful contribution to National income. Farm outputs were too low to meet the individual and household demands in the area, let alone the food demands of other consumers in the state. Such low outputs have more serious implications at the National stage, as more and more resources are being thrown into the agricultural sector year after year to boost production, while the actual production from the use of such resources have not been good enough to meet break-even points, let-alone profits.

\section{Estimated Average Monthly Expenditure on Food}

The monthly expenditure of NGN20, 000 on food by $70.7 \%$ of respondents was found to be low but when put side by side with the fact that most of the food crops produced by respondents is primarily for home consumption, this figure will be expected to go up if the food from own farm were monetized. Some either spent more or less than the values they estimated monthly. In addition to the amounts spent on consumption, some or all of what was produced from the farm by the respondents were consumed at home. As indicated earlier, about $40.7 \%$ of the respondents consumed $81-100 \%$ of their farm outputs, $18.7 \%$ consumed $61-80 \%, 23.3 \%$ consumed $41-60 \%$, and $8 \%$ consumed $21-40 \%$, while a further $9.33 \%$ consumed 1 $20 \%$ of their farm produce.

\subsection{Prevalent Spiritual Beliefs in the Study Area}

The Annang people are highly spiritually inclined and some of the spiritual beliefs prevalent in the area are as listed below:

- When a supposedly healthy person suddenly falls down and dies, then he/she must have been slapped by a ghost or spirit

- When in the farm, one is not expected to answer to one's name if called, as it may be a spirit that is calling

- A sudden awkward silence (especially in a noisy environment like a classroom), means that a ghost is walking past

- Witches influence farming, poverty, disease, accidents, business failures etc

- Everything that happens to everyone was actually pre-determined to happen by fate

- Praying in the morning when one wakes or praying at night before sleep wards off evil and misfortunes for the day/night

- If an enemy gets a picture of you, he/she can exert some diabolical influence over you

- Incisions on specific body parts helps to ward off evil attacks

- If a person attacks you in the dream, then that person is evil

- The mirror is used by witches and occults to monitor the activities of other people

- Wearing Certain amulets or birth stones can bring good luck or ward off evil

- A person's star sign at birth or horoscope defines their future course of actions

- $\quad$ Strange illnesses are caused by unseen evil forces

- $\quad$ Evil persons can use the gifts you give to them to harm you 
- Nocturnal birds (e.g bats) are witches and are often used to accomplish evil deeds

- It is bad for two people walking together, to let another person pass between them

- When you smell sweet food in the night, where there are no houses, then a spirit is cooking

- It is very important to rely on the bible and other spiritual books for guidance and protection

- $\quad$ There are unseen forces in action in the world and they must be appeased from time to time

- If you refer to a person by their names in the night, spirits will know who you are talking about and attack them

- If you point fingers towards a grave or tombstone, the spirits of the dead will get offended and attack you

All these beliefs have not be tested scientifically but they nonetheless influence important decisions at the personal, household and community levels.

\subsection{Respondent's Inclination to Spirituality}

Structured statements reflecting common beliefs in the study area were designed on a four point Likert scale of strongly agree, agree, disagree, or strongly disagree and respondents were asked to indicate their opinions. From Table 2 below, the most accepted statements as indicated by their mean scores were option D ( $\mathrm{x}=3.6600)$, option $\mathrm{C}(\mathrm{X}=3.6400)$ and option I (3.3800). However, option $\mathrm{J}$ had the least mean score $(x=1.8000)$. It is however perceived that some respondents may have had incisions on their body for spiritual purposes, but will not disclose it, as it is supposed to be a secret affair. With mean scores for about 5 options being above 3.0 and only one below 2.0 , respondents had a high inclination to spirituality.

Also, about $59.3 \%$ of the respondents attended religious functions at least once in a week, with a further $26.7 \%$ attending religious functions at least once a month. On religiosity ratings, $56.0 \%$ of the respondents were religious, $42.7 \%$ were extremely religious, while only $1.3 \%$ were non-religious. Put

Table 2: Spirituality Scores of Respondents

\begin{tabular}{|c|c|c|}
\hline S/N & Statements & Mean Scores \\
\hline \hline A & When people keep silent abruptly in a room, a spirit is passing & 2.1400 \\
\hline B & When you smell sweet food at night where there are no houses, then spirits are cooking & 2.1867 \\
\hline C & I rely on the bible and/or other spiritual books for guidance & 3.6400 \\
\hline D & It is very necessary to start and end each day with a prayer & 3.6600 \\
\hline E & I use silence to get in touch with myself & 3.1400 \\
\hline F & I meditate to achieve inner peace & 2.1733 \\
\hline G & The spiritual controls the physical & 2.7533 \\
\hline H & Unseen forces are real and must be appeased & 3.3800 \\
\hline I & Being spiritual/devoted gives my life meaning & 1.8000 \\
\hline J & I have incisions on my body for spiritual reasons & \\
\hline
\end{tabular}

Table 3: Frequency of Attendance at Religious Functions

\begin{tabular}{|c|c|c|}
\hline HOW OFTEN RESPONDENTS ATTENDED RELIGIOUS FUNCTIONS & FREQUENCY & PERCENTAGE \\
\hline \hline Less than once a month & 9 & 6.0 \\
\hline Once a month & 12 & 8.0 \\
\hline Once a week & 40 & 26.7 \\
\hline More than once a week & 89 & 59.3 \\
\hline Total & 150 & 100 \\
\hline
\end{tabular}

Source: Field Survey 2015 
Table 4: Religiosity Rating of Respondents

\begin{tabular}{|c|c|c|}
\hline RELIGIOSITY RATING & FREQUENCY & PERCENTAGE \\
\hline \hline Non-religious & 2 & 1.3 \\
\hline Religious & 84 & 56.0 \\
\hline Extremely religious & 64 & 42.7 \\
\hline Total & $\mathbf{1 5 0}$ & $\mathbf{1 0 0}$ \\
\hline
\end{tabular}

Source: Field survey 2015.

together, $98.7 \%$ of the respondents were active religious individuals.

Furthermore, $62.7 \%$ of the respondents believed in protection from such things as charms, crucifixes, amulets, and other sculptural spiritual representations. Another $64 \%$ believed religious books and stickers could bring good fortunes and ward off evil and $70 \%$ regularly made gestures to the sky, seeking help/guidance/intervention, from a divinity. This portrays a high level of inclination to spirituality by the respondents, and such beliefs and ideas are usually shared among family members, friends and coworkers, while transferring same beliefs to succeeding generations as they grow.

\subsection{Relationship between Socioeconomic Characteristics and Respondents' Inclination to Spirituality}

As shown in the Table $\mathbf{5}$ below, there is no significant relationship between selected socioeconomic characteristics of respondents and their inclination to spirituality. None of the selected independent variables were statistically significant and so, none of the variables could account for the respondents' inclination to spirituality. This will mean that an individual's spirituality is self-defined (may be by one's religious background) and not dependent on any socio-economic or cultural factors. Also in rural communities, the population is relatively homogeneous and differences in their socioeconomic characteristics may not be too significant.

Table 6 below shows the t-test analysis of the difference in the inclinations to spirituality between males and females in the study area. T-test indicated no significant differences in inclinations to spirituality between males and females.

The social environment influences individuals to act and think in a certain way. If individuals in the environment belief in fate, chance, magic and luck, then it is highly possible that most individuals in that environment will be inclined to spirituality, especially in small relatively homogenous rural communities. As noted among respondents in the study area, those who were born and bred or those who had lived in the area for a long time, were more aware of the prevalent spiritual beliefs in the area and more inclined to them,

Table 5: Relationship between Inclination to Spirituality and Selected Characteristics of Respondents

\begin{tabular}{|c|c|c|c|c|}
\hline VARIABLES & COEFFICIENTS & STANDARD ERROR & t & DECISION \\
\hline \hline Sex $_{(\times 1)}$ & -0.538 & 0.651 & -0.82 & Not significant \\
\hline Age $_{(\times 2)}$ & 0.013 & 0.027 & -0.883 & Not significant \\
\hline Years of formal schooling $_{(\times 3)}$ & -0.052 & 0.059 & 0.509 & Not significant \\
\hline Marital status $_{(\times 4)}$ & 0.250 & 0.492 & -0.288 & Not significant \\
\hline Household headshificant $_{(\times 5)}$ & -0.204 & 0.707 & -1.255 & Not significant \\
\hline Household size $_{(\times 6)}$ & -0.085 & 0.067 & -1.509 & Not significant \\
\hline Livelihood activities $_{(\times 7)}$ & -0.775 & 0.513 & 1.112 & Not significant \\
\hline Monthly income $_{(\times 8)}$ & $-6.038 \mathrm{E}-006.766$ & 0.000 & $25.958^{* * *}$ & Not significant \\
\hline Position of leadership $_{(\times 9)}$ & 0.766 & 0.689 & 1.162 & Significant \\
\hline Constant & 30.160 & & & \\
\hline
\end{tabular}

Note: ${ }^{* * *}=$ significant at $1 \%$ level.

Source: SPSS version 20.0 computer printout. 
Table 6: Inclination to Spirituality between Men and Women

\begin{tabular}{|c|c|c|c|c|c|c|}
\hline & $\mathbf{N}$ & $\overline{\mathrm{X}}$ & $\mathbf{S D}_{1}{ }^{2}$ & $\begin{array}{c}\text { Calculated } \\
\mathbf{t}-\text { value }\end{array}$ & $\begin{array}{c}\text { Critical * } \\
\mathbf{t}-\text { value }\end{array}$ & Decision \\
\hline \hline Males & 75 & 28.57 & 6.57 & -1.21 & 1.96 & Not significant \\
\hline Females & 75 & 29.11 & 8.45 & & & \\
\hline
\end{tabular}

*degree of freedom $=148$, level of significance $=0.05$

Where: $\mathrm{n}=$ Number of variables in each group.

$\overline{\mathrm{X}}=$ Mean in each group.

$\mathrm{SD}_{1}{ }^{2}=$ Variance in each group

than those who were foreigners or just visitors in the area. Members of cultural groups and associations were more inclined to spirituality, as well as among individuals who held positions of leadership and authority in the community. Data gathered from the field revealed that those who had cigarettes or alcohol frequently, or took prescription drugs without recommendation were more inclined to luck, fate, chance and were inclined to spirituality. Hard work among those who worked in offices was replaced by discussions on luck, fate and chance by craftsmen and artisans. People, who felt isolated or dejected and individuals who were failures in school were more inclined to spirituality. As the level of income increased and the economic situation improved, the tendency of people to be superstitious decreased, but was not completely absent. The older individuals were inclined to spirituality than the younger ones and female respondents appeared more terrified and concerned about such beliefs, paying attention to them diligently. Individuals who paid more attention to religious activities and were concerned about miracles, mysteries, rituals, sacrifices, taboos, norms, and divinities were inclined to spirituality. Among individuals who held positions of leadership and authority in the community, the levels of inclination were higher even among the few educated ones.

\subsection{Implications of Major Findings for Rural Development}

Data gathered from the research established the following implications for rural development:

\section{Education}

About $94 \%$ of the respondents had acquired formal education of any level. Data gathered from the field revealed that respondents with $1-5$ and $6-10$ years of schooling were more inclined to spirituality than respondents with 11-15 and 16-20 years of formal schooling. With about $61.8 \%$ of individuals with higher educational levels, one will expect that this group (being the majority) will influence and encourage other individuals to lay aside the negative aspects of their beliefs in spirituality, while reinforcing those aspects that help the growth of the community, but the exact reverse has been the case. Every social phenomenon needs some cognitive and concrete requirements to exist and to come into being. Development is a social phenomenon; reaching the goals of development is among the primary goals of every society and reaching development needs concrete and cognitive requirements, without which development cannot be made manifest. These beliefs have left us with individuals without cognitive requirements in the society and it is not necessarily because education is not doing enough to enlighten these individuals, but because the socio-cultural environment imbibes in these individuals, through the process of socialization from birth, different values and orientations to the ones given in classrooms. This is as exemplified in the relationship between the head of the extended family and decisions taken by the nuclear family, in which the extended family is supreme. Again, higher educational status according to Omonona (2001) increases the likelihood of getting paid jobs other than farming in rural areas, but with all the respondents involved actively in farming, it may not be far from the truth to say that the society disregards education and scientific information, making higher educational attainments irrelevant, while still holding ancient interpretations on the causes and effects of certain strange phenomena to be true. The cognitive and the cultural elements of the society are the infrastructure for any kind of economic growth and development and if we must reach the level of other developed and industrial societies in the shortest time possible from the technical and economical points of view, then such a movement requires highly motivated people with a high level of knowledge and high cultural growth. Should the current trend continue, then the problem of agriculture and rural development will never be overcome. 


\section{Religion}

It is impossible to discuss spirituality without mentioning religion, as all religious activities lead to spirituality. About $56 \%$ of the respondents were extremely religious, while a further 42.7 were religious. About $93.3 \%$ of the respondents agreed that religion influenced their lifestyles more than any other thing, and $59.3 \%$ attended religious functions more than once a week. Culturally, individuals within the Annang ethnic group are highly religious and this statistics highlights that with frequent religious activities, production is deprived of required man hours of labour. Also, with consistent participation in religious functions, an individual's level of inclination and reliance on supreme beings and deities increases. It is as Benno Torgler (2007) postulated, that there seems to be a certain concurrence between religiosity and superstitious beliefs.

\section{Low Income Levels, Poor Standard of Living and Poor Infrastructural Development}

These are almost related, as one cannot acquire certain basic amenities with his/her low income level, let alone develop public buildings or provide necessary infrastructures in the community. The primary occupation of the respondents determines the incomes earned by each respondent, and the number of individuals living within family houses is a reflection of the low income level of the people. When accruable monthly income is too low to satisfy household consumption demands, there comes low savings, with low savings low investments, with low investments low productivity, with low productivity low incomes, and this viscous cycle of poverty keeps individuals in the area within poverty lines. While in this state, individuals within the community will continually lack certain basic amenities, public structures and town halls will be outmodern and not properly taken care of, good roads will be notably absent in most parts of the area, water and electricity will be in inadequate supply, and general standard of living was low; as evident in the study area.

\section{Low Agricultural Productivity}

Though all the respondents were involved in one form of agriculture or the other, most of such farming activities were carried out on a subsistence level, with the main aim of providing an additional source of food where monthly income is not sufficient, and selling only after satisfying household food demands have been satisfied. With about $59.4 \%$ of the respondents consuming $61-100 \%$ of their farm outputs, this point is further clarified. With good climate and available land, one will expect that agricultural productivity in the study area will be high and such things as hunger and poverty will be eliminated. One will expect bumper harvests season in-season out, mechanized large scale agriculture in most areas, increased productivity (especially as the government and different NGO'S have shown interest to redevelop the agricultural sector in the country) and increased income from farming activities which will increase agriculture's contribution to the country's GDP, but this has not been the case owing to high levels of inclination to spirituality, already determined in this work. The high mean scores for all three indexes and continuous reliance on supernatural forces to bring certain events to place reflects a high level of fatalism, laziness in carrying out specific responsibilities and duties, and inefficient employment of available human and material resources into producing outputs. Those people who just wait for the invisible and heavenly hands, magicians and sorcerers to help and consider diligent attempts useless could not be good soldiers for the development process.

If increased agricultural productivity and overall rural development in the area is to be achieved, then it is important that such strong inclinations be addressed. But this in itself is a challenge. However, quality and effective education and enlightenment on these beliefs may address this challenge. Education that will provide good exposure to how results are achieved in the outside world, counselling, enlightenment, address inclinations to spirituality properly, provide reorientation on why, how and when events occur in nature backed up by effective means and media through which such education can be delivered to great effect, can help reduce the level of inclinations of farmers in the study area to these beliefs. If the causes and effects of the somewhat supernatural and mystical occurrences can be explained and demonstrated scientifically to farmers, they may come to accept the new knowledge with the proves they have received, and change their attitudes and perceptions towards such things. This will help check their levels of inclination to spirituality. This too, will aid the adoption of innovations in agriculture which will in turn help increase productivity, raise income levels and set the platform for rural development.

\subsection{Conclusion and Recommendations}

An Individual's spirituality is largely propagated by religion, and strong inclinations to spirituality contribute to the low agricultural productivity and poor rural development in the study area. But just as we cannot 
take away culture, traditions, taboos, myths etc. from our social and cultural backgrounds, we cannot also afford to let such distinct attributes affect agriculture and rural development negatively. There has to be a common ground, a common platform, upon which both factors can operate, without being detrimental to the other. Since inclinations relate to reasoning, thoughtfulness and mental tendency, then efforts to reduce levels of inclination to negative aspects of spirituality should be targeted at capturing the thoughts and psyche of individuals in the study area, and the country at large. One such medium capable of capturing the reasoning, thoughts, motives and tendencies of individuals is total education. The following recommendations are presented:

- $\quad$ Agricultural Research Institutes, Universities of Agriculture, Extension Agencies and NGO's should organize learning situations and environments that will pay particular attention to the causes, origin and effects of these inclinations to agriculture and rural development, enlighten individuals on the adoption of improved agricultural practices, and provide counseling, orientation and sensitization programmes that will reduce the levels of inclination to spirituality, superstition and legends

- Individuals must be encouraged to feel more confident, creative, accepted and recognized as an important member of the society and the feeling of powerlessness must be reduced by taking their ideas and thoughts into consideration in making decisions in schools, churches, town halls and social environments in order to tackle isolation and self-alienation.

- Individuals should also be encouraged to participate in scientific research activities and demonstrations. Measures must be put in place to curb the activities of the media propagating the superstitious beliefs and instead use them as teaching platforms to help individuals desist from such thinking and belief patterns.

\section{REFERENCES}

Abhijit, Naik (2010). Religion and Spirituality.http://www.buzzle.com/ articles/superstitiousbeliefs.html.

Ali Sina (October 2012). What is Spirituality? Alisina.org/blog.

AlikShahadah (2002). African Religious Beliefs. There is no Concept of an African Atheist in Antiquity.

ArefehHassani and SanazSadeghi (2014). An investigation of sociological effects of superstitions in people's lifestyle.
Benno Torgler (2007). Determinants of superstition. The Journal of Socio-Economics 36: 5:pp 713-733. http://dx.doi.org/10.1016/j.socec.2007.01.007

Berth, S. A. (2004). "From subsistence to sustainable Agriculture in Africa". Mexico city. Sasakawa Africa Association.

Chav (2011). Causes of superstitious behaviour. blog.lib.umn.edu/chav0084/myblog3 (accessed $7^{\text {th }}$ july 2014).

Compelling Truth (2011). Is there Difference between Religion and Spirituality? www.compellingtruth.org/difference-religionspirituality.html.

Delararei, A. (2004). Theoretical and Practical Research in the Humanities and Social Sciences. Tehran: Roshed Publisher. P.2.

Dominic Umoh (2013). Superstition and Syncretism: Setbacks to Authentic Christian Practice in Africa. International Journal of Humanities and Social Science Invention ISSN (Online), 2319-7722.

Ekong, E.E. (2003). An Introduction to Rural Sociology ( $2^{\text {nd }}$ Edition), Dove Educational Publishers, Uyo, Nigeria. Pp 341-395.

Ebitu, S.E (2004). "The role of Women Co-operatives in enhancing household food security in Uyo Local Government Area of Akwa Ibom State", B. Agric Project, Department of Agricultural Economics and Extension, University of Uyo, Uyo. 64Pp.

FAO (Food and Agriculture Organization of the United Nations) (2001). FAO Bulletin of Statistics, Vol. 2 (2), Rome, Italy.

Fazaei, Y. (2005). Sociology Illusions and Superstitions, Tehran: Chesta, 6(7): 282-483.

FERT (Foundation for Economic Research and Training) 2001. "Poverty profile of Akawa Ibom State", Uyo, Akwa Ibom State. $120 \mathrm{Pp}$

FOS (Federal Office of Statistics) 1999. "Profile for Nigeria 19801996", April.

Hill, P. C., Hood, R. W., McCullough, M. E., Swyers, J. P. and Larson, D. B. (2000). Conceptualizing Religion and Spirituality: Points of Commonality; Points of Departure. Journal for the Theory of Social Behaviour, 30(1): 51-77. http://dx.doi.org/10.1111/1468-5914.00119

Jack Heath, Michael Rennie, Paul Gilding and Alexandra Wille (2014). What is Spirituality? Reachout.com Australia.

John M. Grohol, Psy.D. (2010). Scientific View of Superstitious Behaviour. Kansas State University.

KajaPenia (2014). Psych Basics: Spirituality. www.psychologytoday. com/basics/spirituality.

Kim Falconer (2006). Synchronicity: Meaningful Coincidence or Chance? Kim Falconer Printable Version http://www.falconastrology.com/syn.html

Kofi A.O., D. Tasha, and S. Alik (2012). Religion in Africa and the Diaspora: A Comparative Belief Study.

Lambek, M. (1992). Taboo as a cultural Practice among Malagasy. Speakers. Man, 27(2): pp.245-266.

National Bureau of Statistics (2014). nigerianstat.gov.ng/ (accessed $6^{\text {th }}$ July 2014).

NPC Census (2006). Constitution of the Federal Republic of Nigeria.

Oikeh, J. A. (1980). Health Superstitions among Southern Nigerian Post-Primary School Teachers. Dissertation Abstracts International, 40(85): 4425.

Okoro, G. I (2004). "Perceived effect of oil spillage on the livelihood activities of women in Eastern Obolo Local Governmnet Area of Akwa Ibom State", M.sc. Thesis, Department of Agricultural Extension and Rural Development, University of Ibadan, Ibadan. 120Pp.

Omonona, B. T (2001) "Poverty and its correlates among Rural farming households in Kogi state, Nigeria," Ph.D Thesis, Department of Agricultural Economics, University of Ibadan. 262Pp. 
Purcell, K. (1989). More in Hope than in Anticipation: Fortune Telling and Fatalism among Female Factory Workers: Sociological Factors Abstracts, No. 46.

Rabbi R. S. (2012). Spirituality and Health. Spirituality and Health Media, LLC; 123 Front Street, Suite 2B Traverse City, vMl 49684.

Ruud, J. (1960). Taboo: A Study of Malagasy Customs and Beliefs. Oslo: Oslo University Press. Sepehr, M. (1996).

Sepehr, M. (1996). The Study of Examples, Elements and the Reasons for the Occurrence of Superstitious and False Beliefs.

Sepehr, M. (2005). Ways to Combat Superstition and Calcification. Surveys in Social Research. Allen and Unwin, p.169.

Udo, E. A. (1983). Who are the Ibibio? Onitsha: Africana/FEB Publishers.

Udoh, E. J. (2005). "Demand and Control of Credit from Information Sources by Rice producing women of Akwa lbom State,
Nigeria", Journal of Agriculture and Social Sciences. Vol. 1(2):151-155.

Udoh, E. J and B.T. Omonona (2005). "Adoption and Welfare Impact of Improved Rice Varieties on Rural Farming households in Akwa Ibom State of Nigeria", Integrated Workshop on Rice Policy and Food Security in Sub-Saharan Region, Cotonou, Benin Republic. 14Pp.

Valeed (2011). What are superstitious beliefs? Why do people believe in Superstitions?Hubpages and Hubbers. Copyright (2014).

Wikipedia (2014). Spirituality Definitions - en.m.wikipedia.org (Retrieved July 6).

Zinnbauer, B. J., k. I. Pargament, and Scott, A. B. (1999). The Emerging Meanings of Religiousness and Spirituality: Problems and Prospects. Journal of Personality, 67(6): 888919. http://dx.doi.org/10.1111/1467-6494.00077

(C) 2015 Solomon et al.; Licensee Lifescience Global.

This is an open access article licensed under the terms of the Creative Commons Attribution Non-Commercial License (http://creativecommons.org/licenses/by-nc/3.0/) which permits unrestricted, non-commercial use, distribution and reproduction in any medium, provided the work is properly cited. 